\title{
Achievement Goals, Emotions, Learning, and Performance: A Process Model
}

\author{
John Ranellucci \\ Michigan State University
}

\author{
Nathan C. Hall \\ McGill University
}

\author{
Thomas Goetz \\ University of Konstanz/Thurgau University of Teacher Education
}

\begin{abstract}
The present study evaluates the relations between achievement goals, emotions, learning strategies, and performance as informed by Pekrun's control-value theory of emotions. Undergraduates from various disciplines $(N=203)$ completed domaingeneral, self-report measures in the fall and winter semesters with sessional GPAs evaluated over a 2-year period. Results from cross-lagged and latent growth structural equation models illustrate the benefits of mastery-approach goals for students' emotions, with performance-approach goals predicting less critical thinking, and performance-avoidance goals predicting more anxiety, boredom, critical thinking, and lower achievement gains. Whereas enjoyment was beneficial for most learning strategies, boredom predicted poorer time management, and anxiety predicted lower selfmonitoring and overall GPA. Learning strategies impacted subsequent achievement only in the second semester, with elaboration predicting achievement gains and critical thinking predicting lower overall GPA. Study results provide empirical support for Pekrun's control-value theory and achievement goal theory in showing both direct and indirect effects of students' goals on academic achievement through their emotions and learning strategies.
\end{abstract}

Keywords: academic achievement, achievement emotions, achievement goals, control-value theory, learning strategies

Striving for achievement represents an innate human pursuit as we are constantly seeking to excel in various achievement domains including athletics, business, and education. One of the most prominent theories to emerge over the past 30 years on how individuals think about and

John Ranellucci, Department of Counseling, Educational Psychology, and Special Education, Michigan State University; Nathan C. Hall, Department of Educational and Counselling Psychology, McGill University; Thomas Goetz, Department of Empirical Educational Research, University of Konstanz/Thurgau University of Teacher Education.

This study was supported by research grants to the second author from the Spencer Foundation (201200089) and the Social Sciences and Humanities Research Council of Canada (Partnership Development, 890-2012-0038).

Correspondence concerning this article should be addressed to Nathan C. Hall, Department of Educational and Counselling Psychology, Education Building, Room 543, 3700 McTavish Street, McGill University, Montreal, QC H3A 1Y2, Canada. E-mail: nathan.c.hall@mcgill.ca behave in achievement situations is achievement goal theory (e.g., Dweck, 1986; Elliot, 2005). Despite differences in these varied achievement domains, recent meta-analytic research suggests that the relationship between one's achievement goals and subsequent performance remains remarkably similar across athletic, employment, and educational settings (see Yperen, Blaga, \& Postmes, 2014). Although findings across achievement domains are similar, research on achievement goals has examined these motivational variables primarily in an academic context in which achievement outcomes are frequent and unambiguous, and extended periods of learning allow for the psychological and behavioral effects of students' achievement goals to be more closely examined (e.g., Elliot \& McGregor, 2001).

However, although the relationship between students' achievement goals and their academic performance has received considerable research attention, as evidenced by a number of recent 
meta-analyses and comprehensive reviews (e.g., Huang, 2012; Hulleman, Schrager, Bodmann, \& Harackiewicz, 2010; Linnenbrink-Garcia, Tyson, \& Patall, 2008; Wirthwein, Sparfeldt, Pinquart, Wegerer, \& Steinmayr, 2013), there exists surprisingly little research examining critical mediating factors that may be responsible for this relationship. More specifically, although learning-related emotions (e.g., Daniels et al., 2009; Huang, 2011; Pekrun, Elliot, \& Maier, 2009) and behavioral strategies have been examined as promising mediators of the effects of achievement goals (e.g., Diseth \& Kobbeltvedt, 2010; Liem, Lau, \& Nie, 2008; Muis \& Franco, 2009), few studies to date have investigated the mediating roles of emotions and learning behaviors simultaneously in an effort to better explain how one's achievement goals predict performance. To address this research gap, the present study empirically evaluated the relations between individuals' achievement goals, their learning-related emotions, various learning strategies, and long-term academic performance as informed by theories and research on achievement goals (e.g., Elliot \& Murayama, 2008; Pekrun, Elliot, \& Maier, 2009), self-regulated learning (e.g., Pintrich, 2004), as well as achievement emotions (Pekrun, 2006).

In addition to investigating previously unexplored elements of these theoretical perspectives, this research also expands upon previous research on achievement goals in the following ways. First, this study included a notably diverse sample recruited from various academic disciplines (e.g., biological/physical/health/ computer/social sciences) and evaluated a range of potential mediators including multiple discrete emotions as well as both cognitive and metacognitive learning strategies. Second, the study variables were evaluated at a more hierarchically global level than in prior studies, evaluating new domain-general versions of recent self-report measures (e.g., Elliot \& Murayama, 2008) as well as higher-order achievement outcomes (sessional GPAs across courses). Finally, the study was longitudinal in nature (over two years), allowing for crosslagged analyses and comprehensive latent growth models exploring previously unexamined direct and indirect effects of students' goals on institutional achievement indicators as mediated by emotions and learning strategies.

\section{Achievement Goal Orientations}

Achievement goal orientations refer to the specific reasons that motivate one's behavior in achievement situations (Ames, 1992). More specifically, achievement goals have been defined as a "future-focused cognitive representation that guides behavior to a competencerelated end state that the individual is committed to either approach or avoid" (Hulleman et al., 2010, p. 423). Achievement goals are typically classified based on a $2 \times 2$ taxonomy in which one's motivation to either approach success or avoiding failure is contrasted with one's focus on either developing personal competencies (mastery) or demonstrating one's abilities (performance; Elliot \& McGregor, 2001; Elliot \& Murayama, 2008). As a result, achievement goal research has to date predominantly explored four main goal orientations, with a primary emphasis on mastery-approach goals that involve striving to learn as much as possible; a goal orientation motivated mainly by curiosity, interest, challenge, and improved competence (see Hulleman et al., 2010).

Mastery-approach goals have consistently been found to predict greater enjoyment and less boredom (Daniels et al., 2009; Pekrun et al., 2009), lower levels of anxiety (Daniels et al., 2009), greater use of metacognitive learning strategies (Muis \& Franco, 2009; Vrugt \& Oort, 2008), lower task disengagement (Liem et al., 2008), and greater critical thinking as well as use of cognitive elaboration as a learning strategy (Fenollar, Roman, \& Cuestas, 2007; Liem et al., 2008; Muis \& Franco, 2009). Masteryapproach goals have also been found to have a weak relationship with academic achievement, with some studies showing positive relationships with performance (e.g., Bipp, Steinmayr, \& Spinath, 2012; Bong, 2001; Chen, 2012; Chiang, Yeh, Lin, \& Hwang, 2011) and others reporting no relationship (e.g., Corkin, Yu, \& Lindt, 2011; Elliot \& Murayama, 2008; Harackiewicz, Durik, Barron, Linnenbrink-Garcia, \& Tauer, 2008; Hulleman, Durik, Schweigert, \& Harackiewicz, 2008). Although the relationship between mastery-approach goals and performance in work domains $(r=.27)$ is typically stronger than in athletic or educational settings $(r=.17$ and $r=.13$ respectively, see Yperen et al., 2014), the overall magnitude of this rela- 
tionship is typically weak in achievement domains.

In contrast, performance-avoidance goals involve attempts to conceal the appearance of incompetence or to avoid performing worse than others (see Hulleman et al., 2010 for a comprehensive review) and have typically been found to predict poorer outcomes in achievement settings. More specifically, studies have consistently found individuals who report higher levels of performance-avoidance goals to experience greater anxiety (Pekrun et al., 2009), less frequent use of deep learning strategies (Elliot \& McGregor, 2001), greater use of shallow learning strategies (Diseth \& Kobbeltvedt, 2010; Elliot \& McGregor, 2001; Liem et al., 2008; Muis \& Franco, 2009), higher levels of task disengagement (Liem et al., 2008), less strategic learning (Diseth \& Kobbeltvedt, 2010), as well as lower grades (Elliot \& McGregor, 2001; Pekrun et al., 2009). Related to performance-avoidance goals are performance-approach goals that are less motivated by fear of failure and driven more by a desire to demonstrate superior competence or outperform others (Hulleman et al., 2010). Whereas performance-avoidance goals are consistently maladaptive, the effects of performance-approach goals are more mixed, with findings showing this goal orientation to predict both negative outcomes (e.g., anxiety, Daniels et al., 2009; surface processing, Fenollar et al., 2007) and positive outcomes in academic settings (e.g., deep learning strategies, Diseth \& Kobbeltvedt, 2010; metacognition, Muis \& Franco, 2009; achievement, Pekrun et al., 2009).

Finally, mastery-avoidance goals are conceptualized as involving attempts to avoid learning less than one possibly could (see Hulleman et al., 2010). Although these goals are similar to mastery-approach goals in that they focus on learning, they differ in that they are hypothesized to be motivated instead by a fear of not learning as much as possible. Mastery-avoidance goals also differ from the aforementioned goal orientations in having received considerably less research attention due to typically weak or nonsignificant relations with achievement outcomes (e.g., Elliot \& McGregor, 2001; Elliot \& Murayama, 2008; Yperen et al., 2014) with findings showing this goal orientation to correspond with lower intrinsic motivation (Cury, Elliot, Da Fonseca, \& Moller, 2006) as well as higher levels of anxiety, surface processing, and disorganization (Elliot \& McGregor, 2001). Taken together, extant findings on the effects of individuals' goal orientations in achievement settings show masteryapproach goals to have largely positive effects, performance-avoidance and mastery-avoidance goals to have primarily negative or no effects, and performance-approach goals to have decidedly mixed effects on students' learning and achievement.

\section{Achievement Emotions}

As described above, one's achievement goals can have a significant effect on one's emotions, learning strategies, and achievement levels, with recent research on these relations having been informed primarily by Pekrun's (2006) control-value theory of achievement emotions in which directional relationships between these variables are proposed (see Figure 1; for Pekrun's model applied to nonacademic achievement domains, see Puente-Díaz, 2012). The control-value theory thus provides an integrative framework for investigating the relations between motivational variables, emotions, learning behaviors, and performance in achievement settings and in particular focuses on the structure, antecedents, and outcomes of emotional experiences (for a comprehensive overview, see Pekrun, 2006; Pekrun et al., 2011). "Achievement emotions" refer specifically to learning and performance in achievement settings and are conceptualized as dynamic processes comprised of affective, cognitive, physiological, and behavioral elements (cf. Pekrun, 2006). Unlike moods, discrete achievement emotions are experienced intensely, they are elicited by specific causes (Pekrun, 2006; Rosenberg, 1998), and can be classified based on their valence (positive/negative) and activity level (activating/deactivating; Pekrun, Goetz, Titz, \& Perry, 2002; Russell, 1980; Watson \& Tellegen, 1985). Pekrun's model thus allows researchers to classify individuals' emotions as experienced in achievement settings according to multiple dimensions, most notably the emotions of anxiety (negative/activating), boredom (negative/deactivating), and enjoyment (positive/activating; cf. Daniels et al., 2009; Goetz, Hall, Frenzel, \& Pekrun, 2006; Pekrun, Goetz, Daniels, Stupnisky, \& Perry, 2010). 


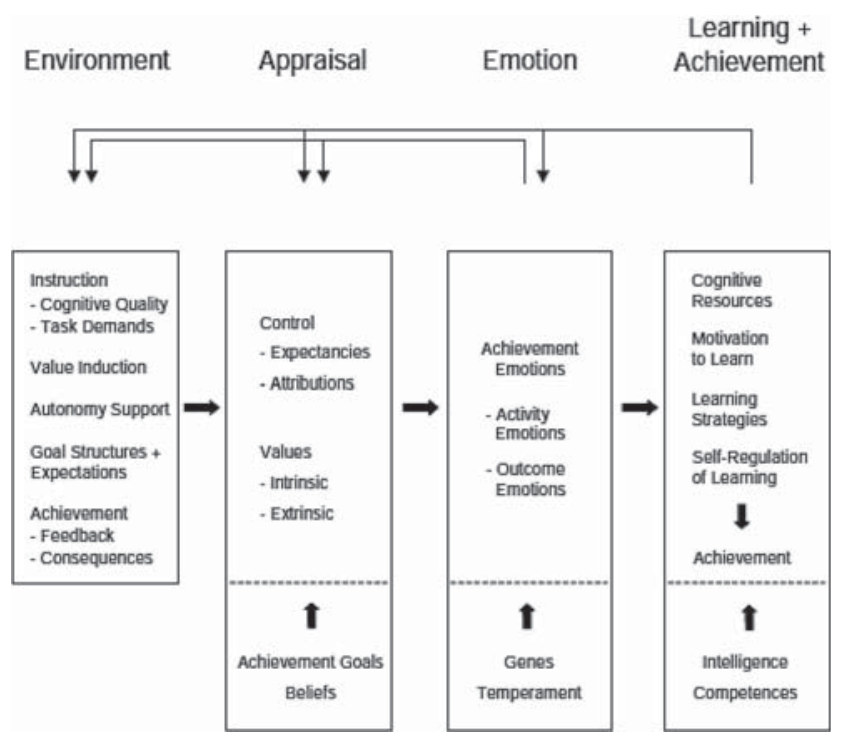

Figure 1. Pekrun's (2006) control-value theory of achievement emotions. From "The Control-Value Theory of Achievement Emotions: Assumptions, Corollaries, and Implications for Educational Research and Practice," by R. Pekrun, 2006, Educational Psychology Review, 18, p. 328. Copyright 2006 by the Springer Science+Business Media, LLC. Adapted with permission.

Concerning the order in which motivation and emotions are assumed to impact performance in academic settings, Pekrun's theory specifically posits that environmental factors, such as instructional quality, classroom goal structures, and prior achievement, form an individuals' cognitive appraisals of the learning situation mainly in terms of their perceptions of control (e.g., perceived competence, expectancies) and value (e.g., perceived usefulness, importance). These cognitive appraisals are then assumed to impact one's emotional experiences that, in turn, lead to specific learning behaviors and achievement outcomes (Pekrun, 2006; Pekrun \& Linnenbrink-Garcia, 2012). Simply put, Pekrun's theory asserts that the learning environment should significantly influence how one thinks and, in turn, how one feels, learns, and performs. Thus, three main links are proposed in Pekrun's control-value theory to account for the relations between motivational, affective, learning, and achievement variables in educational settings with prior research having mainly explored (a) the effects of the educational environment on learners' goals (e.g., classroom goal structures; see James \& Yates, 2007), (b) the effects of achievement goals on emotions in academic settings (e.g., Pekrun et al., 2009), and (c) the effects of one's emotions on learning and achievement as informed by Pekrun's control-value theory (e.g., Villavicencio \& Bernardo, 2013).

With respect to the effects of emotions on learning behaviors and performance, research based on Pekrun's model has consistently found higher enjoyment to predict greater achievement (Daniels et al., 2009; Frenzel, Thrash, Pekrun, \& Goetz, 2007; Goetz, Frenzel, Pekrun, Hall, \& Ludtke, 2007; Pekrun et al., 2002), higher anxiety to predict poorer achievement (Daniels et al., 2009; Meece, Wigfield, \& Eccles, 1990; Pekrun et al., 2009), and greater boredom to similarly predict lower grades (Daniels et al., 2009; Daniels et al., 2008; Pekrun et al., 2009; Pekrun, Hall, Goetz, \& Perry, 2014; Pekrun, 1992; Perry, Hladkyj, Pekrun, \& Pelletier, 2001; Ruthig et al., 2008). Interestingly, the link between ones' emotions and selfregulated learning has received considerably less empirical attention, despite several theoretical models of self-regulated learning in which learning-related emotions are explicitly incorporated (i.e., Efklides, 2011; Pintrich, 2004; Winne \& Hadwin, 1998; Zimmerman, 2000). 
Nevertheless, recent empirical work has shown enjoyment and anxiety to predict learning strategies (e.g., elaboration, rehearsal, problemsolving) and self-regulated learning (e.g., selfmonitoring, planning) in the expected directions (Ahmed, van der Werf, Kuyper, \& Minnaert, 2013; Goetz et al., 2006; Pekrun et al., 2011; Pekrun et al., 2002; Villavicencio \& Bernardo, 2013), with boredom having also been found to predict poorer elaboration and self-regulated learning (Artino \& Jones, 2012; Pekrun et al., 2002, 2010).

\section{Self-Regulated Learning and Achievement}

According to research on self-regulated learning, individuals adopt a variety of strategies to plan, monitor, and regulate their learning, with research in this domain having focused primarily on three adaptive learning and self-regulation strategies: elaboration, critical thinking, and self-monitoring (Pintrich, 2004). Elaboration refers to a class of learning strategies such as paraphrasing, summarizing, or using analogies that build deep connections between prior knowledge and content to be learned (Dole \& Sinatra, 1998; Entwistle, 2000; Pintrich, Smith, Garcia, \& McKeachie, 1991). In contrast, critical thinking refers to analyzing, evaluating, and applying prior knowledge to novel situations and problems (Pintrich, 2004; Pintrich et al., 1991) with self-monitoring involving the evaluation of one's learning progress (Efklides, 2011; Greene \& Azevedo, 2010; Winne \& Hadwin, 1998; Zimmerman \& Campillo, 2003). In addition to these commonly studied learning strategies, other higher-order, self-regulated learning strategies have also traditionally been explored, such as time management, which involves the prioritization of goals and task scheduling so as to optimize learning efforts (Barling, Cheung, \& Kelloway, 1996; Britton \& Tesser, 1991; Macan, Shahani, Dipboye, \& Phillips, 1990).

Empirical research on learning strategies consistently shows elaboration to predict significantly better achievement outcomes (e.g., Albaili, 1998; Hall, Hladkyj, Perry, \& Ruthig, 2004; Hall et al., 2007; Pintrich, Smith, Garcia, \& McKeachie, 1991), with a recent meta-analysis showing a weak positive relationship between critical thinking and achievement (Richardson, Abraham, \& Bond, 2012). Findings from self-regulation stud- ies further show self-monitoring to positively predict achievement, with those who are able to reflect on and regulate their learning typically obtaining better grades (e.g., Dermitzaki, Leondari, \& Goudas, 2009; Perry et al., 2001; for findings concerning conceptual overlap with planning as a self-regulation strategy, see Nett, Goetz, Hall, \& Frenzel, 2012). Although largely overlooked in recent educational psychology research, despite having been incorporated into multiple prominent theories of self-regulated learning (e.g., Pintrich, 2004; Zimmerman, 2000), scattered findings also show time management to typically correspond with better academic performance (MacCann, Fogarty, \& Roberts, 2012; Swart, Lombard, \& de Jager, 2010); a finding replicated in a recent metaanalysis showing time management to positively predict cumulative achievement outcomes (Richardson et al., 2012).

\section{The Present Study}

In an effort to more comprehensively evaluate the relations between individuals' goals and their academic performance, this study followed from theories of achievement goals (e.g., Elliot, 2005), achievement emotions (Pekrun, 2006), and selfregulated learning (e.g., Pintrich, 2004) in evaluating a comprehensive analytical model in which hypothesized causal relations between individuals' goals, emotions, learning, and achievement were simultaneously assessed. Although these hypotheses were evaluated in the academic domain to facilitate comparisons with prior goal research conducted primarily in educational settings (see Elliot \& McGregor, 2001), these findings are generalizable across achievement domains as illustrated by recent meta-analytic research on crossdomain similarity in goal-performance relations (Yperen et al., 2014).

In line with previous research (e.g., Daniels et al., 2009; Liem et al., 2008; Pekrun et al., 2009), the present study employed a trichotomous model of achievement goals in evaluating the effects of mastery-approach, performanceapproach, and performance-avoidance goals on students' emotions, albeit utilizing a new domain-general version of a recent achievement goals measure (AGQ-R; Elliot \& Murayama, 2008). Concerning the achievement emotions assessed, this research is also consistent with prior studies in evaluating a positive-activating emotion (enjoyment), a negative-activating 
emotion (anxiety), as well as a negativedeactivating emotion (boredom) as potential mediators of the effects of goals on achievement outcomes as assessed using a recently developed self-report measure (Pekrun et al., 2011). With respect to learning behaviors, four learning strategies consistently found to predict better performance were evaluated, namely elaboration, self-monitoring, critical thinking, and time management. Whereas the benefits of elaboration and self-monitoring are most commonly explored, the relatively underexplored strategies of critical thinking (e.g., Phan, 2009; Villavicencio, 2011) and time management (e.g., MacCann et al., 2012; Richardson et al., 2012) were also assessed to more comprehensively evaluate individuals' learning strategies as potential mediators of goal-achievement relations. Finally, this study expanded on recent achievement goals research (e.g., Daniels et al., 2009; Muis \& Franco, 2009; Pekrun et al., 2009) in evaluating longer-term and more global achievement outcomes (sessional GPAs over two years) in a notably diverse student sample (e.g., STEM, social science disciplines) as part of previously unexamined cross-lagged and latent growth structural equation models of hypothesized relations between students' goals, emotions, learning behaviors, and achievement.

Hypothesis 1: Achievement goals and emotions. The first link postulated in Pekrun's control-value theory is from achievement goals to emotions related to learning and achievement. Consistent with recent research on achievement emotions exploring learning-related affective experiences beyond anxiety (Zeidner, 1998), the present study also evaluated the emotions of boredom (e.g., Nett, Goetz, \& Daniels, 2010; Nett, Goetz, \& Hall, 2011; Pekrun et al., 2010) and enjoyment (e.g., Goetz, Frenzel, Hall, \& Pekrun, 2008; Goetz et al., 2006; Schukajlow et al., 2012). Following from recent studies examining students' emotions as mediators of goal-achievement relations (Daniels et al., 2009; Pekrun et al., 2009), mastery-approach goals were expected to positively predict enjoyment and negatively predict boredom, whereas performance-approach and performanceavoidance goals were expected to positively predict anxiety. Extending prior research exploring stability and change in achievement goals over time (e.g., Fryer \& Elliot, 2007; Muis \& Edwards, 2009), the present study further investigated change in achievement goals as antecedents of emotions, learning strategies, and academic achievement. Specific effects of stability versus change in achievement goal orientations on emotions were not hypothesized because of a lack of longitudinal research on the effects of change in these constructs on postsecondary student development (cf. change in high-school students' achievement goals as a function of mastery-structured environments: O'Keefe, Ben-Eliyahu, \& LinnenbrinkGarcia, 2013; achievement effects for primary/secondary students: Murayama, Pekrun, Lichtenfeld, \& vom Hofe, 2013).

Hypothesis 2: Emotions and learning strategies. The second link postulated in control-value theory suggests that one's use of learning strategies is most proximally predicted by one's achievement emotions. More specifically, positiveactivating emotions (e.g., enjoyment) should predict more flexible and creative learning strategies such as elaboration. In contrast, negative-activating emotions (e.g., anxiety) should predict more rigid learning strategies such as rehearsal, and negative-deactivating emotions (e.g., boredom) are hypothesized to lead to surface processing strategies (Pekrun, 2006). In accordance with Pekrun's control-value theory and recent research on emotions and self-regulated learning (e.g., Ahmed et al., 2013; Artino \& Jones, 2012; Pekrun et al., 2002, 2011), enjoyment was therefore hypothesized to positively predict more adaptive learning strategies (e.g., elaboration, critical thinking) and self-regulation strategies (e.g., self-monitoring, time management) whereas anxiety and boredom were expected to negatively predict both types of strategies.

Hypothesis 3: Learning strategies and achievement. Following from the third hypothesized link in Pekrun's model, it was further expected that each learning and self-regulation strategy assessed would positively predict academic achievement. 
Consistent with extant empirical research in the domain of self-regulated learning, long-term achievement outcomes were expected to be positively predicted by the cognitive learning strategies of cognitive elaboration (e.g., Hall et al., 2007; Pintrich, Smith, Garcia, \& McKeachie, 1993; Richardson et al., 2012) and critical thinking (e.g., Muis \& Franco, 2009; Phan, 2008). It was also anticipated that longterm achievement would be positively predicted by more higher-order self-regulation variables, namely self-monitoring (e.g., Dermitzaki et al., 2009; Nett et al., 2012) and time management (e.g., MacCann et al., 2012; Swart et al., 2010). As no research to date has investigated change in academic achievement in relation to achievement goals, emotions, and learning strategies, no specific hypotheses were proposed regarding achievement gains.

\section{Method}

\section{Participants and Procedure}

Undergraduate students at a research-intensive North American university were recruited to participate in a two-part, Web-based study in exchange for an entry in a prize draw $(\sim 200)$. The program affiliations of study participants were notably varied, including social sciences/ ecology (37\%), physical/biological sciences (28\%), humanities/fine arts (13\%), engineering $(9 \%)$, computer sciences (3\%), and other disciplines (10\%; e.g., education, health sciences, interdisciplinary). The mean age of the participants was 19.75 years $(S D=1.87), 35 \%$ were female, $73 \%$ reported English as their first language, and the ethnic distribution of the sample was 56\% Asian American/Pacific Islander, 29\% Caucasian, 5\% Latino/Latina, 2\% Chicano/ Chicana, and $9 \%$ multiracial/other. The mean high-school grade of participants was $89.22 \%$ $(S D=5.56)$, with an approximately equal distribution of students across the four years of undergraduate studies (range $=25-26 \%$ per year). Participants were recruited by e-mail from faculty deans and student affairs offices, and completed the questionnaire at two time points including three months into the fall term (Time $1, N=203$ ) and at the end of the winter term six months later (Time $2, N=138$ ). Par- ticipant attrition was comparable with previous achievement goal studies with undergraduates (32\%; cf. 30\%, Daniels et al., 2009), and institutional data (e.g., sessional GPAs) were obtained for all participants from the university registrar's office.

\section{Study Measures}

Given the notably heterogeneous nature of the study sample, the self-report measures were largely adapted from published measures of achievement goals, emotions, and learning strategies to be domain-general in nature (i.e., preambles and items refer not to a specific class, but one's courses more generally). Means, standard deviations, ranges, and alpha levels are presented in Table 1, with additional descriptive analyses showing acceptable ranges for skewness $(-1.28$ to 0.30$)$ and kurtosis $(-0.52$ to 3.22) for all study variables.

Achievement goals. Students' achievement goal orientations were measured with domain-general measures adapted from Elliot and Murayama's (2008) Achievement Goal Questionnaire-Revised (AGQ-R), using three items per measure evaluated on a 5-point Likert scale ranging from 1 (strongly disagree) to 5 (strongly agree). The three goals orientations assessed included mastery-approach goals $(\alpha \mathrm{s}=.84 / .86$; e.g., "My aim is to completely master the material presented in class"), performance-approach goals $(\alpha \mathrm{s}=.87 / .91$; e.g., "I am striving to do well compared to other students"), and performance-avoidance goals $(\alpha s=.89 / .91$; "My goal is to avoid learning less than I possibly could"). Consistent with previous research on goal-achievement relations (Huang, 2012; Hulleman et al., 2010), masteryavoidance goals were not assessed following from prior studies showing generally weak or nonsignificant relations with academic performance (e.g., Elliot \& McGregor, 2001; Elliot \& Murayama, 2008) and theoretically inconsistent relations with other affective and learning variables (e.g., Cury et al., 2006; Elliot \& McGregor, 2001).

Achievement emotions. Students' emotions specific to learning and achievement settings were measured using domain-general versions of three subscales from Pekrun et al.'s (2011) Achievement Emotions Questionnaire (AEQ). The three emotions assessed included 
Table 1

Descriptive Statistics for Study Measures

\begin{tabular}{lcccr}
\hline \multicolumn{1}{c}{ Variable } & Observed range & $M$ & $S D$ & $\alpha$ \\
\hline MAP & $1.33-5.00 / 2.00-5.00$ & $3.86 / 3.70$ & $0.80 / 0.78$ & $0.84 / 0.86$ \\
PAP & $1.00-5.00 / 1.00-5.00$ & $3.98 / 3.80$ & $0.90 / 0.95$ & $0.87 / 0.91$ \\
PAV & $1.50-5.00 / 1.00-5.00$ & $3.87 / 3.70$ & $1.06 / 1.03$ & $0.89 / 0.91$ \\
Enjoyment & $1.00-5.00 / 1.40-5.00$ & $3.10 / 3.05$ & $0.66 / 0.65$ & $0.83 / 0.84$ \\
Anxiety & $1.00-4.64 / 1.00-4.64$ & $2.80 / 2.73$ & $0.78 / 0.81$ & $0.87 / 0.90$ \\
Boredom & $1.00-5.00 / 1.00-4.82$ & $2.84 / 2.83$ & $0.84 / 0.78$ & $0.92 / 0.91$ \\
Self-monitoring & $1.25-5.00 / 1.00-5.00$ & $3.61 / 3.58$ & $0.67 / 0.76$ & $0.73 / 0.82$ \\
Critical thinking & $1.00-7.00 / 1.00-7.00$ & $4.32 / 4.37$ & $1.26 / 1.18$ & $0.89 / 0.90$ \\
Elaboration & $1.33-7.00 / 2.00-7.00$ & $5.11 / 5.00$ & $0.98 / 0.95$ & $0.77 / 0.77$ \\
Time management & $1.78-4.56 / 1.22-4.22$ & $3.04 / 3.02$ & $0.52 / 0.54$ & $0.83 / 0.85$ \\
Fall GPA 2007 & $0.68-4.00$ & 3.22 & 0.60 & - \\
Winter GPA 2008 & $0.00-4.00$ & 3.24 & 0.61 & - \\
Fall GPA 2008 & $1.33-4.00$ & 3.26 & 0.55 & - \\
Winter GPA 2009 & $1.75-4.00$ & 3.27 & 0.55 & - \\
\hline
\end{tabular}

Note. Time 1/Time 2. MAP = Mastery-approach goals; PAP = Performance-approach goals; PAV = Performanceavoidance goals.

enjoyment (10 items, $\alpha \mathrm{s}=.83 / .84$; e.g., "I look forward to studying"), anxiety (11 items, $\alpha=$ $.87 / .90$; e.g., "I get tense and nervous while studying,"), and boredom (11 items, $\alpha=.92 /$. 91; e.g., "Studying for my courses bores me"). Participants responded on a 5-point Likert scale ranging from 1 (strongly disagree) to 5 (strongly agree).

Self-regulated learning. Two learning strategies were assessed using domain-general versions of measures from Pintrich et al.'s (1991) Motivated Strategies for Learning Questionnaire (MSLQ), namely critical thinking (five items, $\alpha \mathrm{s}=.89 / .90$; e.g., "I treat course material as a starting point and try to develop my own ideas about it") and cognitive elaboration (six items, $\alpha \mathrm{s}=.77$; e.g., "I try to relate ideas in a subject to those in other courses whenever possible"), each evaluated on a 7-point Likert scale ranging from 1 (not at all true of me) to 7 (very true of me). Participants additionally completed measures of time man agement from Britton and Tesser's (1991) Time Management Questionnaire (TMQ; 18 items $\alpha s=.83 / .85$; e.g., "Do you have a set of goals for the entire semester?") and self-monitoring adapted from Perry et al. (2001; four items, $\alpha \mathrm{s}=.73 / .82$; e.g., "When I study, I can recognize when I've studied enough to pass a test") each on a 5-point Likert scale ranging from 1 (never) to 5 (very often).

Academic performance. Noncumulative grade point averages (GPAs) obtained from the university registrar's office for all participants were evaluated as objective indicators of student achievement. Achievement data was assessed over a 2-year period and included four sessional GPA measures from the Fall 2007, Winter 2008, Fall 2008, and Winter 2009 semesters. Whereas the effects the aforementioned self-report measures assessed at Time 1 were evaluated on the GPAs for all four semesters, the effects of these measures at Time 2 were assessed on GPA data for the last three semesters.

\section{Results}

\section{Correlations}

As outlined in Tables 2 and 3, the magnitude and directions of the correlations at Times 1 and 2 , and between these two time points, are largely consistent with existing literature, including largely positive correlations among the goal orientation variables, as well as within the negative emotions, self-regulation strategies, and achievement measures. Most notably, a strong correlation between performanceapproach and performance-avoidance goals was observed despite differential correlations with all other variables, underscoring the importance of evaluating these measures as independent constructs despite their phenotypic similarity (cf. Linnenbrink-Garcia et al., 2012; Murayama, Elliot, \& Yamagata, 2011). A weak 
positive relationship between mastery-approach goals and performance-avoidance goals was also observed, consistent with prior research showing weak relations (e.g., Kaplan, Lichtinger, \& Gorodetsky, 2009) or no relation between these measures (e.g., Hulleman et al., 2010).

The pattern of correlations between achievement goals and emotions was also consistent with previous studies in showing stronger relations between students' emotions and mastery-approach goals than with performance-approach or performance-avoidance goals (e.g., Daniels et al., 2009; Pekrun et al., 2009). Additionally, masteryapproach goals more strongly corresponded to adaptive learning strategies than the performance orientations, with relations between performanceavoidance goals and the learning variables proving largely nonsignificant.

The emotions of enjoyment and boredom were correlated with each learning strategy in the expected directions, with anxiety consistently corresponding to lower self-monitoring. Further, sessional GPAs were found to most strongly and consistently correlate with elaboration and anxiety in the expected directions, with time management correlating with achievement in the same semester, goals correlating with achievement only in the first semester, and boredom mainly correlating with achievement in the next semester (cf. Pekrun et al., 2014).

Finally, the pattern of correlations between Time 1 and Time 2 variables (see Table 3 ) was largely in accordance with the patterns reported within each time point. As would be expected for longitudinal analyses, the magnitudes of these correlations were typically smaller than those observed within each time point, with some values no longer reaching statistical significance. Notably, the relations between emotions and other variables remained fairly stable, with the magnitude of some correlations being larger between time points than observed within a given assessment. For example, the correlations at Time 2 between mastery-approach goals and enjoyment $(r=.38)$, anxiety $(r=$ $-.14)$, and boredom $(r=-.31)$ were lower than those observed between Time 2 masteryapproach goals and Time 1 emotions $(r \mathrm{~s}=.45$, -.23 , and -.44 , respectively). Overall, the relations between mastery-approach goals and all other variables remained largely significant, highlighting the importance of mastery-approach goals not only within a semester but over 
Table 3

Zero-Order Correlations Between Self-Report Study Measures (Between Times 1 and 2)

\begin{tabular}{|c|c|c|c|c|c|c|c|c|c|c|}
\hline \multirow[b]{2}{*}{ Time 1 variables } & \multicolumn{10}{|c|}{ Time 2 variables } \\
\hline & 1 & 2 & 3 & 4 & 5 & 6 & 7 & 8 & 9 & 10 \\
\hline 1. MAP & $.46^{* * *}$ & $.30^{*}$ & $.22^{*}$ & $.38^{* *}$ & -.06 & $-.40^{* *}$ & $.26^{* *}$ & $.21^{*}$ & $.25^{* *}$ & $.25^{* * *}$ \\
\hline 2. PAP & $.31^{* * *}$ & $.52^{* * *}$ & $.41^{\text {*** }}$ & $.29^{* * *}$ & .14 & -.04 & $.30^{* * *}$ & $.19^{*}$ & $.22^{*}$ & .18 \\
\hline 3. PAV & $.25^{* *}$ & $.39^{* * *}$ & $.40^{* *}$ & .13 & $.20^{*}$ & .11 & .16 & $.22^{*}$ & .15 & -.00 \\
\hline 4. Enjoyment & $.45^{* *}$ & $.24^{*}$ & .13 & $.62^{* *}$ & -.11 & $-.51^{* *}$ & $.19^{*}$ & $.25^{* * *}$ & $.27^{* * *}$ & $.43^{* *}$ \\
\hline 5. Anxiety & $-.23^{*}$ & -.14 & -.04 & -.12 & $.70^{* *}$ & $.48^{* *}$ & $-.34^{* *}$ & $-.24^{*}$ & $-.22^{*}$ & -.16 \\
\hline 6. Boredom & $-.44^{* *}$ & -.15 & -.08 & $-.49^{* *}$ & $.38^{* *}$ & $.75^{* *}$ & $-.25^{* *}$ & $-.29^{* *}$ & $-.26^{* *}$ & $-.47^{* *}$ \\
\hline 7. Self-monitoring & $.26^{* *}$ & $.30^{* * *}$ & .04 & $.24^{*}$ & -.18 & $-.41^{* *}$ & $.46^{* *}$ & $.26^{* * *}$ & $.28^{* *}$ & $.19^{*}$ \\
\hline 8. Critical thinking & $.29^{\text {*** }}$ & .09 & .08 & .07 & .03 & -.14 & .18 & $.51^{* *}$ & $.20^{*}$ & -.01 \\
\hline 9. Elaboration & $.26^{* *}$ & .20 & .05 & $.21^{*}$ & -.09 & $-.27^{* * *}$ & $.27^{* *}$ & $.19^{*}$ & $.42^{* *}$ & $.31^{*}$ \\
\hline 10. Time management & $.28^{* * *}$ & $.24^{* * *}$ & .17 & $.26^{* *}$ & .03 & $-.29^{* *}$ & .13 & .09 & $.25^{* *}$ & $.74^{* *}$ \\
\hline
\end{tabular}

Note. Internal consistency estimates are presented in bold along the diagonal. MAP $=$ Mastery-approach goals; PAP $=$ Performance-approach goals; PAV = Performance-avoidance goals

${ }^{*} p<.05 . \quad{ }^{* * *} p<.01$.

the academic year. Concerning relations between the same variable at Times 1 versus 2 , these values were consistently moderate to high in magnitude ( $r s=.40$ to .75 ) and the highest correlation observed for every construct, indicating high internal consistency for all selfreport measures. Most notably, the autocorrelations were particularly high for the emotion measures (enjoyment, $r=.62$; anxiety, $r=.70$; boredom, $r=.75)$ and the metacognitive learning strategy of time management $(r=.74)$, showing these constructs to be especially stable over time.

\section{Cross-Lagged Models}

As outlined in Figure 2, two sets of crosslagged structural equation models were evalu-

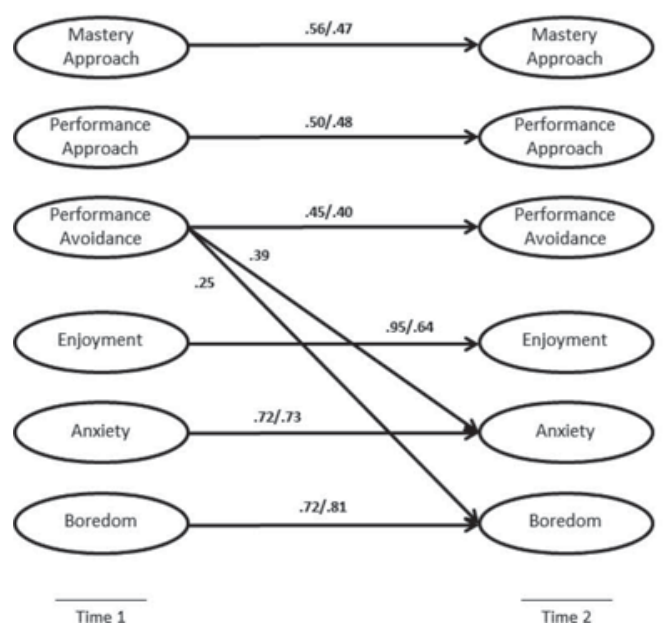

B
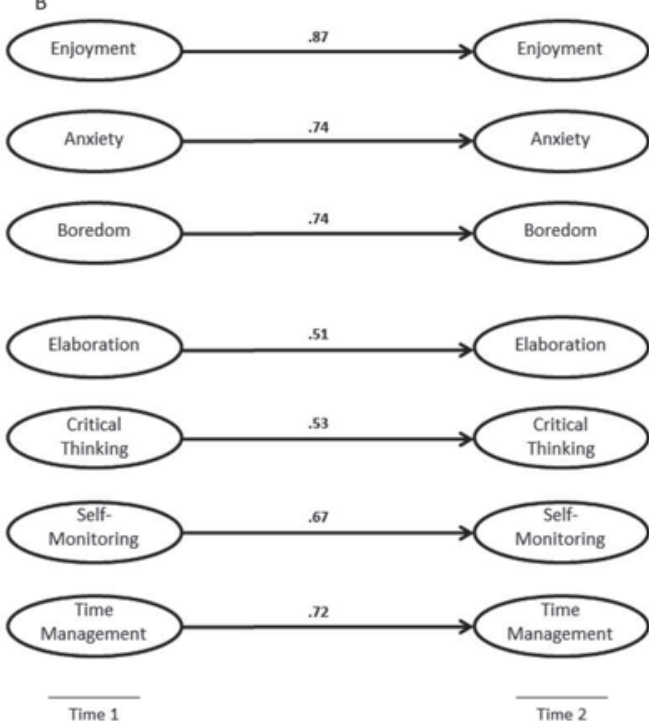

Figure 2. Cross-lagged analyses of achievement goals and emotions (Panel A) and emotions and learning strategies (Panel B). For Panel A, values for goals-to-emotions/emotions-togoals models are indicated separately. All displayed paths are significant at $p<.05$. Nonsignificant paths and covariances are not displayed. 
ated to determine the extent of empirical support for the two hypothesized sets of directional relations between our self-report study measures (Hypothesis 1 in Panel A: goals $\rightarrow$ emotions; Hypothesis 2 in Panel B: emotions $\rightarrow$ learning strategies). First, each model included all variables of the same construct type (e.g., all achievement goal orientations simultaneously) to ensure observed effects of specific variables were not attributable to overlap with related constructs (e.g., performance-approach and performance-avoidance). Second, each model evaluated only two construct types (e.g., goals vs. emotions) as an omnibus model with all latent self-report variables failed to iterate due to complexity. Third, in addition to autoregressive paths between the same variable across time points, correlations were modeled between each construct within a given time point, as were correlations between error terms for the same manifest variable at each time point to account for potential systematic response bias. Finally, each model included cross-paths from all variables within a given construct type (e.g., each emotion) at Time 1 to all variables of the other construct type (e.g., each learning strategy) at Time 2, and did not include cross-paths between variables within a construct type to minimize model complexity and focus explicitly on crossconstruct directional relations as outlined in the study hypotheses.

Panel A of Figure 2 presents the results of a modified cross-lagged analysis of achievement goals and learning-related emotions as addressed in Hypothesis 1. As initial model findings were uninterpretable because of multicollinearity between mastery-approach goals and enjoyment (latent correlation at Time $1=.78$ ), including a Heywood case (enjoyment autoregression $\beta=1$ ) and spurious suppression (Time 1 mastery-approach goals to Time 2 enjoyment $\beta=-.48, p<.05$ vs. Time $1 / 2 r=.38, p<$ .01 ; see Table 3 ), a modified version was assessed. As recommended by Burkholder and Harlow (2003), a modified cross-lagged analysis was conducted in two stages: the first evaluating only cross-paths from goals to emotions, and the second modeling only cross-paths from emotions to goals (retaining the requisite initial correlation between mastery-approach goals and enjoyment). The modified analyses were interpretable and the fit was satisfactory for the goals-to-emotions model: $\chi^{2}(531)=889.35$, $p<.000, \mathrm{CFI}=.911, \mathrm{RMSEA}=.058$; and the emotions-to-goals model: $\chi^{2}(531)=900.59$, $p<.000$, CFI $=.908$, RMSEA $=.059$. As outlined in Figure 2 (Panel A), the only significant cross-paths showed achievement goals to predict emotions, with performance-avoidance goals at Time 1 predicting higher levels of both anxiety and boredom at Time 2 .

Panel B of Figure 2 presents the cross-lagged model evaluating directional relations between learning-related emotions and learning strategies as addressed in Hypothesis 2. The initial analysis fit the data well, $\chi^{2}(503)=710.592$, $p<.000$, CFI $=.939$, RMSEA $=.045$, and showed no significant effects of Time 1 emotions on Time 2 learning strategies, nor effects of Time 1 learning strategies on Time 2 emotions. Overall, the results of our preliminary cross-lagged analyses provide support for Hypothesis 1 in showing achievement goals to more significantly predict subsequent emotions than vice versa (i.e., performance-avoidance goals and negative emotions), but do not support Hypothesis 2 concerning the effects of emotions on learning strategies. However, as the present findings do not alternatively show effects of learning strategies on emotions, likely due to the highly stable nature of these constructs over time, these findings do not preclude our evaluation of hypothesized effects of emotion on learning in subsequent mediational models as supported by Pekrun's control-value theory and existing research on emotions and learning outcomes (e.g., Ahmed et al., 2013; Artino \& Jones, 2012; Pekrun et al., 2002, 2010, 2011).

\section{Latent Change Models}

Following from the preceding cross-lagged results and Pekrun's control-value theory, latent growth structural equation models were conducted to evaluate the three study hypotheses to evaluate the effects of achievement goals (mastery approach, performance approach, performance avoidance) on learning-related emotions (enjoyment, anxiety, boredom), the effects of emotions on self-regulated learning (elaboration, critical thinking, self-monitoring, time management), and the effects of learning strategies on long-term achievement (GPA intercept/slope over time). Additionally, the effects of stability versus change over time in achieve- 
ment goal orientations on subsequent emotions, learning, and achievement were examined to address a lack of prior research examining the effects of temporal variability in these constructs on postsecondary student development. In Model 1, the effects of goals, emotions, and learning variables at Time 1 (first semester) were evaluated on overall GPA (intercept) and linear growth in GPA (slope) over a 2-year period (four semesters, Fall 2007 to Winter 2009 , regression weights set to $0,1,2$, and 3 ; for latent growth curve analysis protocols, see Byrne, 2010). In Model 2, the effects of the same self-report measures assessed at Time 2 (second semester) were evaluated on GPA intercept and slope over a 1.5 -year period ( 3 semesters, Winter 2008 to Winter 2009, regression weights set to 0,1 , and 2).

Finally, Model 3 evaluated the effects of stability (latent intercepts) and change over time (latent slopes) for each achievement goal orientation (from Time 1 to 2) on students' subsequent emotions and learning strategies (Time 2) as well as GPA trajectories (3 semesters). Latent intercepts and slopes for the emotion and learning behavior variables were not evaluated because of notably high temporal stability relative to the achievement goal measures (autoregressive $\beta s=.67-.87$; see Table 3 ). Each model was fully recursive in including direct paths between all antecedent and outcome variables to more conservatively evaluate the magnitude of the proposed indirect paths controlling for direct relations. Correlations were additionally included among latent variables of a given construct type (e.g., within achievement goals) to account for conceptual overlap, with parceling (random item selection attributable to high factor loadings, unidimensional indicators, and a large set of items) employed for all self-report variables except achievement goals (3 items per scale) to increase parsimony (e.g., multiple scales include $>10$ items; for more on parceling protocols, see Little, Cunningham, Shahar, \& Widaman, 2002; Little, Rhemtulla, Gibson, \& Schoemann, 2013).

Model 1 (first semester, 2-year GPA). The first model resulted in satisfactory fit: $\chi^{2}(370)=570.62, p<.000, \mathrm{CFI}=.934, \mathrm{RM}-$ $\mathrm{SEA}=.052$ (see Figure 3). Mastery-approach goals positively predicted enjoyment and negatively predicted anxiety and boredom, whereas the paths from the performance goals to emotions did not reach significance. Enjoyment positively predicted greater reported use of elaboration, critical thinking, and self-monitoring, with anxiety predicting lower self-monitoring and boredom predicting poorer time manage-

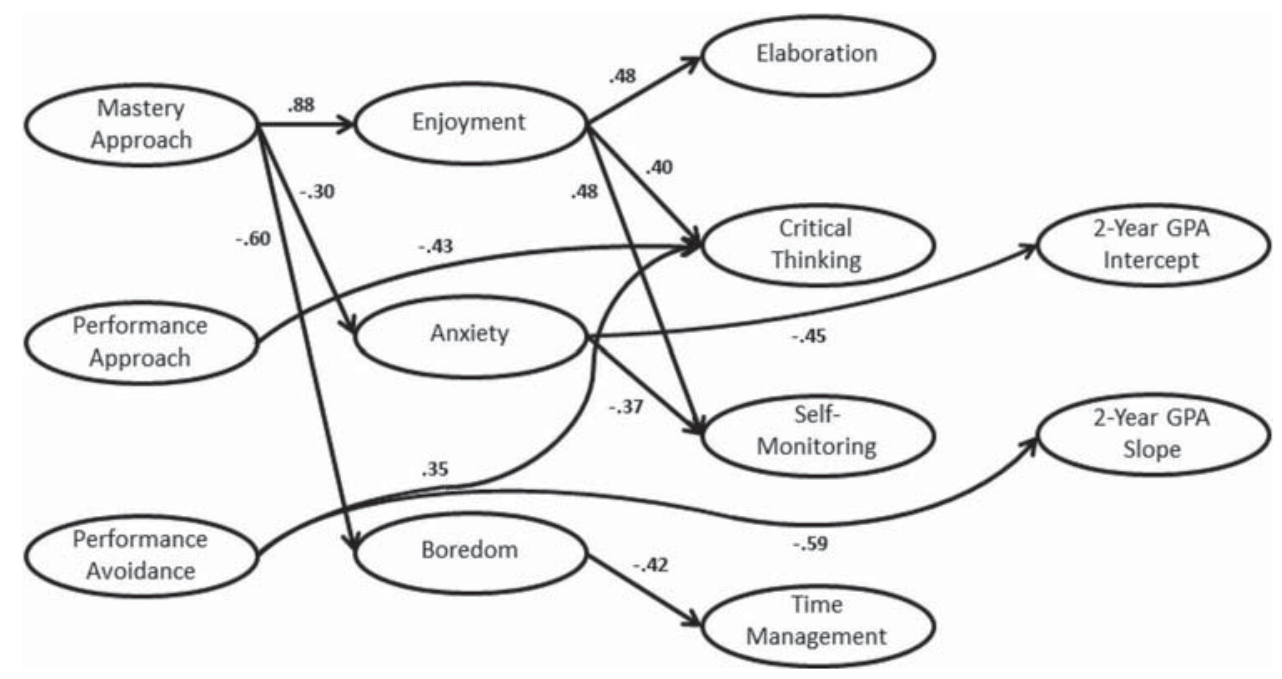

Figure 3. Structural equation model of the effects of Time 1 (first semester) goal orientations, emotions, and learning strategies on achievement over four subsequent semesters. All paths are significant at $p<.05$. Nonsignificant paths and correlations within construct types are not displayed. 
ment. In terms of the relations between selfregulated learning and achievement, learning strategies did not significantly predict GPA intercept or slope. However, direct negative effects of performance-avoidance goals and anxiety were found on GPA intercept and slope, respectively. Whereas higher levels of performance-avoidance goals predicted a lower likelihood of improvement in GPA over the following four semesters, greater anxiety predicted generally lower sessional GPAs over time. Finally, two additional significant paths were observed in Model 1 showing performanceapproach goals to predict lower levels of critical thinking, and performance-avoidance goals to predict higher levels of critical thinking.

Model 2 (second semester, 1.5-year GPA). The second model demonstrated satisfactory fit: $\chi^{2}(340)=545.586, p<.000$, CFI $=.912$, RMSEA $=.055$ (see Figure 4 ). The path coefficients observed were largely consistent with those of Model 1, with replicated paths being generally lower in magnitude. More specifically, mastery-approach goals predicted greater enjoyment and lower boredom, with enjoyment, in turn, predicting greater self-regulation (elaboration, critical thinking, self-monitoring), and boredom predicting poorer time management.
Similarly, anxiety continued to predict lower self-monitoring, and performance-approach goals again corresponded to lower levels of critical thinking. With respect to differences between the models, paths in Model 1 that were no longer significant in Model 2 included the effects of mastery-approach goals on anxiety, of performance-avoidance goals on critical thinking, and of performance-avoidance goals and anxiety on long-term achievement. However, multiple paths that were not significant in Model 1 were significant in Model 2. Concerning the hypothesized effects of achievement goals, performance-avoidance goals were found to predict greater anxiety, whereas masteryapproach goals were found to directly predict greater learning strategy use with respect to elaboration and critical thinking. Finally, both hypothesized and unanticipated effects of selfregulated learning variables were found on achievement, with elaboration found to predict greater improvement in GPA over three semesters, and critical thinking corresponding to lower overall GPA levels over time.

Model 3 (first-to-second semester, 1.5-year GPA). The third model also provided a satisfactory fit to the data: $\chi^{2}(607)=993.340$, $p<.000, \mathrm{CFI}=.891, \mathrm{RMSEA}=.056(\mathrm{see}$

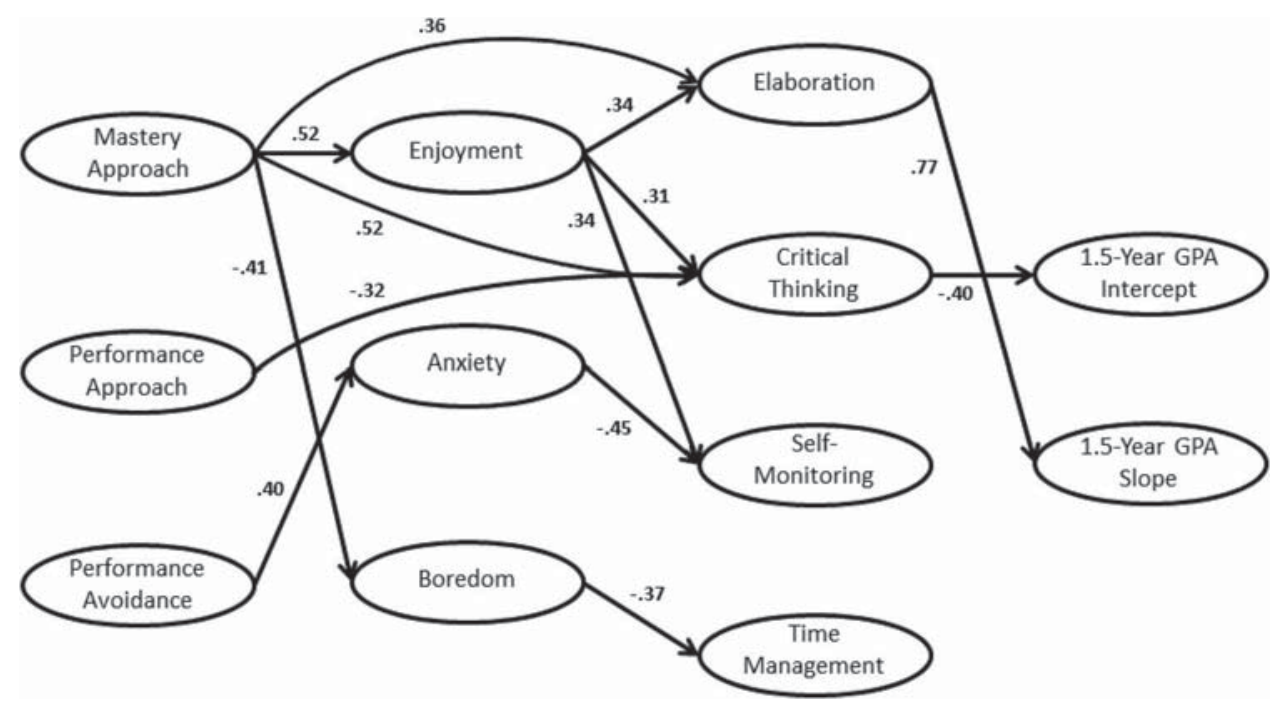

Figure 4. Structural equation model of the effect of Time 2 (second semester) goal orientations, emotions, and learning strategies on achievement over three subsequent semesters. All paths are significant at $p<.05$. Nonsignificant paths and correlations within construct types are not displayed. 
Figure 5). As noted above, this analysis replicated Model 2 with the notable exception of evaluating the effects of stability (latent intercepts) and change (latent slopes) from the first to second semester for each achievement goal orientation on emotions and learning strategies in the second semester, and GPA levels over three subsequent semesters. Concerning the effects of the latent intercepts and slopes for the achievement goal measures, the findings observed largely replicated those in the preceding models. More specifically, students with consistently high mastery-approach goals reported greater enjoyment and critical thinking, as well as lower boredom, with students who increased in masteryapproach goals reporting even higher enjoyment and critical thinking, as well as more elaboration. Additionally, students with either consistently high or increased performanceavoidance goals reported more anxiety, with students who became more performanceapproach oriented reporting lower levels of critical thinking later in the year.

Despite this consistent pattern of results, however, this model evaluating the effects of stability and change in achievement goals revealed two unanticipated findings. First, stu- dents who reported consistently high levels of performance-avoidance goals throughout the academic year were found to also report greater boredom - an effect that did not reach significance in either the first- and secondsemester models. Second, higher levels of enjoyment in the second semester were found to predict a lower likelihood of improvement in GPAs over the following three semesters. Whereas this path was marginally significant in Model 2 ( $\beta=-.54, p=.056)$, this effect was more evident when stability and change in achievement goals was accounted for $(\beta=$ $-.60, p=.046)$. Finally, although two previously significant paths from enjoyment to critical thinking and self-monitoring were no longer observed, all other significant paths from the emotion and learning strategy variables in Model 2 remained significant in Model 3.

\section{Discussion}

\section{Support for Study Hypotheses}

The purpose of the present study was to empirically investigate multiple underexplored links between students' achievement goal ori-

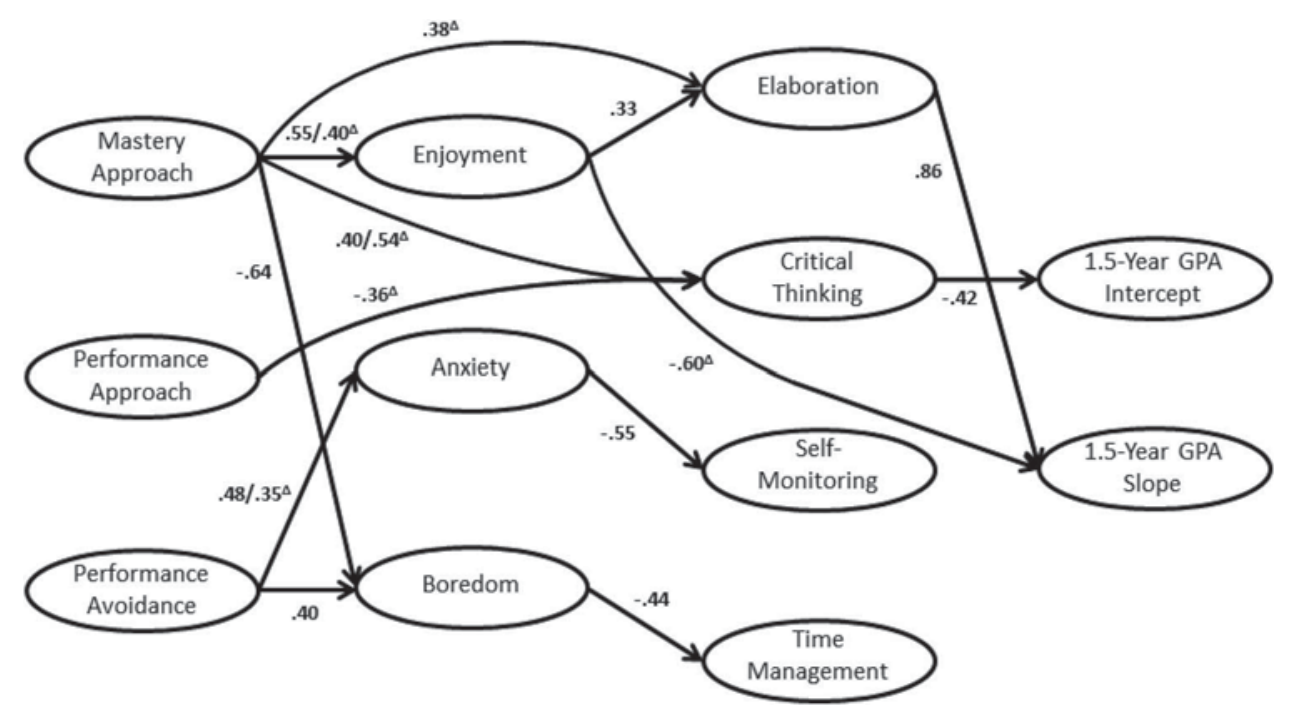

Figure 5. Structural equation model of the effects of latent intercepts/change $(\Delta)$ in achievement goal orientations (first to second semester) on emotions and learning strategies (second semester) and achievement over three subsequent semesters. All paths are significant at $p<$ .05 . Nonsignificant paths and correlations within construct types are not displayed. 
entations, learning-related emotions, selfregulated learning behaviors, and performance outcomes as outlined in the control-value theory of achievement emotions and achievement goal research. More specifically, this study entailed a comprehensive analysis of three core sets of hypotheses evaluated using multiple recent selfreport measures and long-term achievement indicators for a cross-disciplinary sample, and further explored how these relations may change over time. With respect to Hypothesis 1, our cross-lagged, cross-sectional, and latent change results were consistent with extant research in showing students' achievement goals to predict their emotional experiences while learning. First, mastery-approach goals predicted lower anxiety in the first semester, as well as greater enjoyment and lower boredom throughout the academic year, with increases in mastery-approach goals over time further contributing to enjoyment of learning. Additionally, higher levels or increases in performanceavoidance goals were found to predict both greater anxiety and boredom, albeit mainly later in the academic year, underscoring the notably adverse emotional impact of this goal orientation.

In accordance with Hypothesis 2, students' emotions were, in turn, found to significantly predict learning-related outcomes, most notably with respect to positive effects of learningrelated enjoyment on students' use of elaboration and critical thinking as cognitive learning strategies, and self-monitoring as a metacognitive learning approach. Anxiety was also found to consistently predict lower self-monitoring, a finding in line with research showing anxiety to compete with higher-order learning processes for cognitive resources (see Eysenck, Derakshan, Santos, \& Calvo, 2007). Moreover, negative effects of boredom on students' higherorder time management abilities were observed, an interesting finding consistent with studies showing feelings of boredom to correspond with perceptions of time passing slowly (Acee et al., 2010; Pekrun et al., 2010). Given that the effects of emotions on self-regulated learning were observed both at the outset and end of the academic year, these results further highlight the importance of maintaining optimal emotional learning experiences throughout the learning process.
Finally, study findings provide partial empirical support for Hypothesis 3 in showing cognitive elaboration, when assessed later in the academic year, to positively predict an increase in academic achievement over the following three semesters. Thus, given prior studies primarily exploring relations between elaboration and single achievement indicators, this result contributes to the research on self-regulated learning in showing this core learning strategy to also predict significant linear increases in noncumulative, composite indicators of college student achievement over a 1.5-year period.

Despite the overall pattern of results largely supporting the study hypotheses, a number of hypothesized paths did not reach significance. For example, performance-approach goals did not predict higher levels of anxiety, enjoyment did not predict time management, negative emotions (anxiety and boredom) did not negatively predict cognitive learning strategies, and the only self-regulation variable found to predict achievement in the hypothesized direction was cognitive elaboration. Although this lack of results may be attributable to typically weak relations having been observed for some variables in previous research (e.g., performanceavoidance/anxiety; Pekrun et al., 2009), it is also possible that the simultaneous, competitive evaluation of multiple variables in the SEM analyses (in contrast to Daniels et al., 2009), or the cross-domain nature of the present measures and sample, may have contributed to nonsignificant effects (e.g., domain-specificity in achievement goals, Bong, 2001; learningrelated emotions, Goetz et al., 2007). For example, in contrast to self-regulated learning studies demonstrating the differential utility of learning strategies depending on the domain (see Alexander, Dinsmore, Parkinson, \& Winters, 2011), the present domain-general investigation intentionally employed more global variants of learning-related measures that may have allowed only the more generalizable learning approaches to predict achievement, namely elaboration.

\section{Contributions to Achievement Goal Research}

In addition to providing partial support for Hypothesis 1 concerning achievement goal effects, the overall results contribute to achieve- 
ment goal research in three important ways. First, our findings are consistent with studies showing a small yet positive relationship between mastery goals and achievement (see Hulleman et al., 2010), and further suggest that whereas mastery-approach goals may predict better grades earlier in the learning process as a result of lower anxiety, higher levels or increases in mastery goals also predict achievement gains later on as a result of beneficial effects on enjoyment and, in turn, elaborative learning strategy use. Second, our results are also relevant to several studies reporting no relation between mastery goals and performance (i.e., Elliot \& McGregor, 2001; Elliot \& Murayama, 2008; Harackiewicz et al., 2008; Hulleman et al., 2008; Senko \& Miles, 2008) in showing mastery-approach goals to have ambivalent effects on cumulative achievement as a result of also having not only positive but negative effects on students' grades by way of other emotion and learning variables.

More specifically, whereas higher or increased mastery-approach goals positively predicted elaboration by the second semester, resulting in subsequent achievement gains, consistently high or increased mastery goals also predicted greater critical thinking that, in turn, led to lower overall grades. Additionally, latent change analyses showed students who reported consistently high or increased mastery goals to experience higher levels of enjoyment that, in turn, predicted learning strategies that by the second semester could both help (elaboration) and hurt (critical thinking) their chances of GPA improvements over time. These findings thus provide unique empirical evidence for why mastery-approach goals may not show linear positive relations with achievement outcomes in suggesting that mastery-oriented students may experience positive emotions and use learning strategies that can compromise achievement outcomes or gains due to their explicit focus on personal learning goals as opposed to imposed performance indicators (cf. negative effects of interest-based studying for mastery-oriented students; Senko, Hama, \& Belmonte, 2013; Senko \& Miles, 2008).

Third, the present results provide a unique domain-general perspective on the long-term effects of performance-related goals on learning behaviors and achievement. More specifically, our findings suggest that students endorsing performance-approach goals may, in part, obtain better grades not only by engaging primarily in shallow learning strategies (e.g., Midgley, Kaplan, \& Middleton, 2001), but also by avoiding learning strategies involving deeper reflection and equivocation, namely critical thinking. Additionally, our results expand on prior research showing performance-avoidance to predict generally lower achievement levels (see Hulleman et al., 2010) in demonstrating significant negative effects of performance-avoidance goals specifically on subsequent increases in GPA over the next two years. In other words, these findings are consistent with achievement goal theory in suggesting that although performance-avoidant students may invest some effort to avoid performance declines (i.e., maintain status quo), their intentional withholding of the effort required for meaningful learning gains (e.g., self-handicapping) actively prevents them from improving their performance.

\section{Critical Thinking: A Risky Strategy?}

In direct contrast to the study hypotheses, two unanticipated sets of findings were observed with respect to critical thinking, highlighting the potential maladaptive nature of this learning strategy at the domain-general level. First, the maladaptive nature of this strategy for achievement was suggested by students who endorsed performance-approach goals consistently avoiding this strategy, resulting in better year-end grades, with students who endorsed achievement-limiting performance-avoidance goals reporting greater critical thinking. Second, whereas learning strategies were found to predict achievement later in the learning process, consistent with their later temporal sequencing in Pekrun's control-value theory, elaboration led to performance gains whereas critical thinking predicted poorer overall grades. Thus, contrary to prior research on critical thinking showing a positive relationship with achievement (e.g., Muis \& Franco, 2009; Phan, 2008), this finding is instead consistent with studies showing weak or nonsignificant relations with performance (e.g., Bers, McGowan, \& Rubin, 1996; Facione \& Facione, 1997; Giancarlo \& Facione, 2001; Komarraju \& Nadler, 2013; Stupnisky, Renaud, Daniels, Haynes, \& Perry, 2008; for meta-analytic findings, see Richardson et al., 2012). 
More specifically, although the correlations observed between GPA outcomes and critical thinking were near zero at both time points (Time $1 \mathrm{rs}=.02,-.01,-.02,-.04$; Time 2 $r \mathrm{~s}=-.01,-.04,-.03), \mathrm{SEM}$ results further suggested that critical thinking was unlikely to be used by successful students and may have a significant negative effect on academic achievement. Whereas this finding might suggest a suppression effect, all variance inflation factors were below 3 indicating limited multicollinearity (see O'Brien, 2007). As such, although this result may have resulted from overlapping variance with multiple related variables, it is more likely attributable to methodological factors such as the timing and/or domain-general nature of the self-report and achievement measures.

With respect to methodological considerations, it is also possible that the benefits of critical thinking for performance may be specific to certain domains or evaluation methods, such as open-ended, take-home essays in the social sciences requiring students to compare and contrast competing perspectives. Conversely, this strategy may be ineffective or maladaptive on time-limited, recall-oriented evaluations in natural science courses (e.g., multiple-choice, short answer) for which surface-oriented learning strategies (e.g., rehearsal, drill and practice) may be more effective and efficient than cost-benefit analyses. As such, given that approximately half of the present study sample was recruited from STEM domains (e.g., biological/physical/health/computer sciences, engineering), it is possible that the domain-general nature of the critical thinking and achievement measures may have masked positive relations previously found in students recruited from social science programs (e.g., Muis \& Franco, 2009; Phan, 2008; for more on the domain-specificity of critical thinking, see Ennis, 1989; Sá, West, \& Stanovich, 1999; Toplak \& Stanovich, 2002).

Concerning the timing of the critical thinking effects, it is also important to note that negative effects were not found for critical thinking in the first semester but rather only near the end of the academic year. As such, whereas critical thinking may be expected during the learning process to contrast and compare multiple unfamiliar perspectives, critical thinking later in the academic year may instead indicate uncertainty and insufficient cognitive processing. This explanation is consistent with research on episte- mological beliefs suggesting that relativism (i.e., critical thinking) should ideally lead to evaluatism (i.e., an integrated, holistic understanding) in order for meaningful knowledge gains to occur (e.g., Hofer, 2001; Murphy \& Mason, 2006). However, this assertion should also be considered tentative given limited research on, and the theoretically debated nature of, developmental changes in the utility of critical thinking with respect to learning and achievement outcomes.

Finally, a potential motivational explanation for the observed negative relationship between critical thinking and achievement suggest that this learning strategy may represent an intentional decision by students to foster personal development and well-being at the expense of achievement gains. For instance, it is possible that students having a vested interest in a specific topic may devote disproportionate effort toward researching consistent and contrary evidence concerning that topic in assigned readings, thus choosing to neglect less engaging content to be included on the upcoming exam in favor of personal learning goals. This assertion is consistent with recent research by Senko and Miles (2008) suggesting that mastery-oriented students prefer to study content of interest over content to be assessed, and is further supported by mastery-approach goals positively predicting critical thinking in the second semester. Moreover, critical thinking may represent an attempt to preserve one's emotional well-being by perseverating on topics that are less ego-threatening (e.g., due to difficulty or personal sensitivity), consistent with the present findings showing performance-avoidance to also predict greater critical thinking. Taken together, whereas the correlations between critical thinking and other study variables (i.e., mastery, enjoyment, boredom, elaboration, self-monitoring) were as anticipated in showing this learning strategy to be beneficial for students, the negative effects on achievement may be attributable to methodological or motivational issues warranting further empirical investigation.

\section{Study Limitations}

In addition to the aforementioned contributions of the present study, three primary limitations in the present study design warrant consideration. First, as this study focused only on 
typically adaptive learning and metacognitive strategies, surface-level processes such as rehearsal were excluded, likely contributing to largely nonsignificant paths from performanceoriented goals to learning and, in turn, achievement outcomes. As such, future research in which students' goal orientations, emotions, and achievement are assessed with respect to long-term achievement gains is recommended. A second limitation concerns the use of selfreport measures, as opposed to behavioral or trace data, to assess students' achievement goals, emotions, and particularly their learning behaviors. Although the present study used validated instruments with acceptable reliability, Greene and Azevedo (2010) advise caution when using questionnaire measures to assess self-regulated learning because of inaccurate and aggregate reporting that may limit variability and reliability of responses. Finally, whereas experimental evaluations of the effects of students' motivational beliefs on emotions and learning outcomes are often recommended (e.g. Pekrun, 2006), so as to highlight the relevance of motivational constructs for academic development (e.g., Anderman, 2011), the present study used only correlational methods warranting further experimental research in which the observed effects of domain-general achievement goals, emotions, and learning strategies are explicitly evaluated.

In conclusion, the results of this study provide empirical support for Pekrun's controlvalue theory of achievement emotions and achievement goal theory in underscoring the affective and learning benefits, as well as possible achievement risks, of students' masteryapproach goals, as well as the adverse effects of performance-oriented goals on negative affect, learning behaviors, and achievement gains. Moreover, these results show previously unobserved positive effects of students' elaborative learning strategies on performance improvements over time, as well as achievement deficits resulting from performance-avoidance goals and critical thinking strategies, highlighting these variables as warranting future investigation in intervention studies (e.g., elaboration training, King, 1992) and classroom research (e.g., classroom goal structures, Anderman et al., 2001). Finally, the present findings demonstrate the unique roles played by students' discrete emotions in mediating the effects of achievement goals on learning and performance, underscoring the importance of further developing programs aimed at facilitating emotionally adaptive learning environments (e.g., value-enhancement; Hulleman et al., 2010) and instructional methods (e.g., teacher enthusiasm; Frenzel, Goetz, Ludtke, Pekrun, \& Sutton, 2009) so as to promote meaningful long-term gains in learning and achievement in educational settings.

\section{References}

Acee, T. W., Kim, H., Kim, H. J., Kim, J.-I., HsiangNing, R. C., Kim, M., . . . Wicker, F. W. (2010). Academic boredom in under- and overchallenging situations. Contemporary Educational Psychology, 35, 17-27. http://dx.doi.org/10.1016/j.cedpsych .2009 .08 .002

Ahmed, W., van der Werf, G., Kuyper, H., \& Minnaert, A. (2013). Emotions, self-regulated learning, and achievement in mathematics: A growth curve analysis. Journal of Educational Psychology, 105, 150-161. http://dx.doi.org/10.1037/ a0030160

Albaili, M. A. (1998). Goal orientations, cognitive strategies and academic achievement among United Arab Emirates college students. Educational Psychology, 18, 195-203. http://dx.doi.org/ 10.1080/0144341980180205

Alexander, P. A., Dinsmore, D. L., Parkinson, M. M., \& Winters, F. I. (2011). Self-regulated learning in academic domains. In B. Zimmerman \& D. Schunk (Eds.), Handbook of self-regulation of learning and performance. New York, NY: Routledge. Ames, C. (1992). Classrooms: Goals, structures, and student motivation. Journal of Educational Psychology, 84, 261-271. http://dx.doi.org/10.1037/ 0022-0663.84.3.261

Anderman, E. M. (2011). Educational psychology in the twenty-first century: Challenges for our community. Educational Psychologist, 46, 185-196. http://dx.doi.org/10.1080/00461520.2011.587724

Anderman, E. M., Eccles, J. S., Yoon, K. S., Roeser, R., Wigfield, A., \& Blumenfeld, P. (2001). Learning to value mathematics and reading: Relations to mastery and performance-oriented instructional practices. Contemporary Educational Psychology, 26, 76-95. http://dx.doi.org/10.1006/ceps.1999 .1043

Artino, A. R., Jr., \& Jones, K. D., II. (2012). Exploring the complex relations between achievement emotions and self-regulated learning behaviors in online learning. The Internet and Higher Education, 15, 170-175. http://dx.doi.org/10.1016/j .iheduc.2012.01.006 
Barling, J., Cheung, D., \& Kelloway, E. K. (1996). Time management and achievement striving interact to predict car sales performance. Journal of Applied Psychology, 81, 821-826. http://dx.doi .org/10.1037/0021-9010.81.6.821

Bers, T. H., McGowan, M., \& Rubin, A. (1996). The disposition to think critically among community college students: The California critical thinking disposition inventory. The Journal of General Education, 45, 197-223.

Bipp, T., Steinmayr, R., \& Spinath, B. (2012). A functional look at goal orientations: Their role for self-estimates of intelligence and performance. Learning and Individual Differences, 22, 280289. http://dx.doi.org/10.1016/j.lindif.2012.01.009

Bong, M. (2001). Between- and within-domain relations of academic motivation among middle and high school students: Self-efficacy, task value, and achievement goals. Journal of Educational Psychology, 93, 23-34. http://dx.doi.org/10.1037/ 0022-0663.93.1.23

Britton, B. K., \& Tesser, A. (1991). Effects of timemanagement practices on college grades. Journal of Educational Psychology, 83, 405-410. http://dx .doi.org/10.1037/0022-0663.83.3.405

Burkholder, G. J., \& Harlow, L. L. (2003). An illustration of a longitudinal cross-lagged design for larger structural equation models. Structural Equation Modeling, 10, 465-486. http://dx.doi.org/ 10.1207/S15328007SEM1003_8

Byrne, B. M. (2010). Structural equation modeling with AMOS: Basic concepts, applications, and programming (2nd ed.). New York, NY: Taylor and Francis Group.

Chen, J. A. (2012). Implicit theories, epistemic beliefs, and science motivation: A person-centered approach. Learning and Individual Differences, 22, 724-735. http://dx.doi.org/10.1016/j.lindif .2012.07.013

Chiang, Y., Yeh, Y., Lin, S. S. J., \& Hwang, F. (2011). Factor structure and predictive utility of the $2 \times 2$ achievement goal model in a sample of Taiwan students. Learning and Individual Differences, 21, 432-437. http://dx.doi.org/10.1016/j .lindif.2011.02.011

Corkin, D. M., Yu, S. L., \& Lindt, S. F. (2011) Comparing active delay and procrastination from a self-regulated learning perspective. Learning and Individual Differences, 21, 602-606. http://dx.doi .org/10.1016/j.lindif.2011.07.005

Cury, F., Elliot, A. J., Da Fonseca, D., \& Moller, A. C. (2006). The social-cognitive model of achievement motivation and the $2 \times 2$ achievement goal framework. Journal of Personality and Social Psychology, 90, 666-679. http://dx.doi.org/ 10.1037/0022-3514.90.4.666

Daniels, L. M., Haynes, T., Stupnisky, R., Perry, R. P., Newall, N., \& Pekrun, R. (2008). Individual differences in achievement goals: A longitudinal study of cognitive, emotional, and achievement outcomes. Contemporary Educational Psychology, 33, 584-608. http://dx.doi.org/10.1016/j.cedpsych .2007 .08 .002

Daniels, L. M., Stupnisky, R. H., Pekrun, R., Haynes, T. L., Perry, R. P., \& Newall, N. E. (2009). A longitudinal analysis of achievement goals: From affective antecedents to emotional effects and achievement outcomes. Journal of Educational Psychology, 101, 948-963. http://dx.doi.org/ 10.1037/a0016096

Dermitzaki, I., Leondari, A., \& Goudas, M. (2009). Relations between young students' strategic behaviors, domain-specific self-concept, and performance in a problem-solving situation. Learning and Instruction, 19, 144-157. http://dx.doi.org/ 10.1016/j.learninstruc.2008.03.002

Diseth, A., \& Kobbeltvedt, T. (2010). A mediation analysis of achievement motives, goals, learning strategies, and academic achievement. British Journal of Educational Psychology, 80, 671-687. http://dx.doi.org/10.1348/000709910X492432

Dole, J. A., \& Sinatra, G. M. (1998). Reconceptualizing change in the cognitive construction of knowledge. Educational Psychologist, 33, 109128. http://dx.doi.org/10.1080/00461520.1998 .9653294

Dweck, C. S. (1986). Motivational processes affecting learning. American Psychologist, 41, 10401048. http://dx.doi.org/10.1037/0003-066X.41.10 .1040

Efklides, A. (2011). Interactions of metacognition with motivation and affect in self-regulated learning: The MASRL model. Educational Psychologist, 46, 6-25. http://dx.doi.org/10.1080/00461520 .2011 .538645

Elliot, A. J. (2005). A conceptual history of the achievement goal construct. In A. J. Elliot \& C. S. Dweck (Eds.), Handbook of competence and motivation (pp. 52-72). New York, NY: Guilford Press.

Elliot, A. J., \& McGregor, H. A. (2001). A $2 \times 2$ achievement goal framework. Journal of Personality and Social Psychology, 80, 501-519. http:// dx.doi.org/10.1037/0022-3514.80.3.501

Elliot, A. J., \& Murayama, K. (2008). On the measurement of achievement goals: Critique, illustration, and application. Journal of Educational Psychology, 100, 613-628. http://dx.doi.org/10.1037/ 0022-0663.100.3.613

Ennis, R. H. (1989). Critical thinking and subjective specificity: Clarification and needed research. $E d-$ ucational Researcher, 18, 4-10. http://dx.doi.org/ 10.3102/0013189X018003004

Entwistle, N. J. (2000). Approaches to studying and levels of understanding: The influences of teaching 
and assessment. In J. C. Smart \& W. G. Tierney (Eds.), Higher education: Handbook of theory and research (Vol. 15, pp. 156-218). New York, NY: Agathon Press.

Eysenck, M. W., Derakshan, N., Santos, R., \& Calvo, M. G. (2007). Anxiety and cognitive performance: Attentional control theory. Emotion, 7, 336-353. http://dx.doi.org/10.1037/1528-3542.7.2.336

Facione, N. C., \& Facione, P. A. (1997). Critical thinking assessment in nursing education programs: An aggregate data analysis. Millbrae, CA: California Academic Press.

Fenollar, P., Román, S., \& Cuestas, P. J. (2007). University students' academic performance: An integrative conceptual framework and empirical analysis. British Journal of Educational Psychology, 77, 873-891. http://dx.doi.org/10.1348/ 000709907X189118

Frenzel, A. C., Goetz, T., Ludtke, O., Pekrun, R., \& Sutton, R. E. (2009). Emotional transmission in the classroom: Exploring the relationship between teacher and student enjoyment. Journal of Educational Psychology, 101, 705-716. http://dx.doi .org/10.1037/a0014695

Frenzel, A. C., Thrash, T. M., Pekrun, R., \& Goetz, T. (2007). Achievement emotions in Germany and China: A cross-cultural validation of the Academic Emotions Questionnaire-Mathematics (AEQ-M). Journal of Cross-Cultural Psychology, 38, 302309. http://dx.doi.org/10.1177/0022022107300276

Fryer, J. W., \& Elliot, A. J. (2007). Stability and change in achievement goals. Journal of Educational Psychology, 99, 700-714. http://dx.doi.org/ 10.1037/0022-0663.99.4.700

Giancarlo, C. A., \& Facione, P. A. (2001). A look across four years at the disposition toward critical thinking among undergraduate students. The Journal of General Education, 50, 29-55. http://dx.doi .org/10.1353/jge.2001.0004

Goetz, T., Frenzel, A. C., Hall, N. C., \& Pekrun, R. H. (2008). Antecedents of academic emotions: Testing the internal/external frame of reference model of academic enjoyment. Contemporary Educational Psychology, 33, 9-33. http://dx.doi.org/ 10.1016/j.cedpsych.2006.12.002

Goetz, T., Frenzel, A. C., Pekrun, R., Hall, N. C., \& Ludtke, O. (2007). Between- and within-domain relations of students' academic emotions. Journal of Educational Psychology, 99, 715-733. http://dx .doi.org/10.1037/0022-0663.99.4.715

Goetz, T., Hall, N. C., Frenzel, A. C., \& Pekrun, R. (2006). A hierarchical conceptualization of enjoyment in students. Learning and Instruction, 16, 323-338. http://dx.doi.org/10.1016/j.learninstruc .2006 .07 .004

Greene, J. A., \& Azevedo, R. (2010). The measurement of learners' self-regulated cognitive and metacognitive processes while using computer- based learning environments. Educational Psychologist, 45, 203-209. http://dx.doi.org/10.1080/ 00461520.2010 .515935

Hall, N. C., Hladkyj, S., Perry, R. P., \& Ruthig, J. C. (2004). The role of attributional retraining and elaborative learning in college students' academic development. The Journal of Social Psychology, 144, 591-612. http://dx.doi.org/10.3200/SOCP .144.6.591-612

Hall, N. C., Perry, R. P., Goetz, T., Ruthig, J. C., Stupnisky, R. H., \& Newall, N. E. (2007). Attributional retraining and elaborative learning: Improving academic development through writingbased interventions. Learning and Individual Differences, 17, 280-290. http://dx.doi.org/ 10.1016/j.lindif.2007.04.002

Harackiewicz, J. M., Durik, A. M., Barron, K. E., Linnenbrink-Garcia, L., \& Tauer, J. M. (2008). The role of achievement goals in the development of interest: Reciprocal relations between achievement goals, interest, and performance. Journal of Educational Psychology, 100, 105-122. http://dx .doi.org/10.1037/0022-0663.100.1.105

Hofer, B. K. (2001). Personal epistemology research: Implications for learning and teaching. Educational Psychology Review, 13, 353-383. http://dx .doi.org/10.1023/A:1011965830686

Huang, C. (2011). Achievement goals and achievement emotions: A meta-analysis. Educational Psychology Review, 23, 359-388. http://dx.doi.org/ 10.1007/s10648-011-9155-X

Huang, C. (2012). Discriminant and criterion-related validity of achievement goals in predicting academic achievement: A meta-analysis. Journal of Educational Psychology, 104, 48-73. http://dx.doi .org/10.1037/a0026223

Hulleman, C. S., Durik, A. M., Schweigert, S. B., \& Harackiewicz, J. M. (2008). Task values, achievement goals, and interest: An integrative analysis. Journal of Educational Psychology, 100, $398-$ 416. http://dx.doi.org/10.1037/0022-0663.100.2 .398

Hulleman, C. S., Godes, O., Hendricks, B. L., \& Harackiewicz, J. M. (2010). Enhancing interest and performance with a utility value intervention. Journal of Educational Psychology, 102, 880895. http://dx.doi.org/10.1037/a0019506

Hulleman, C. S., Schrager, S. M., Bodmann, S. M., \& Harackiewicz, J. M. (2010). A meta-analytic review of achievement goal measures: Different labels for the same constructs or different constructs with similar labels? Psychological Bulletin, 136, 422-449. http://dx.doi.org/10.1037/a0018947

James, V. H., \& Yates, S. H. (2007). Extending the multiple goal perspective to tertiary classroom goal structures. International Education Journal, $8,68-80$. 
Kaplan, A., Lichtinger, E., \& Gorodetsky, M. (2009). Achievement goal orientations and self-regulation in writing: An integrative perspective. Journal of Educational Psychology, 101, 51-69. http://dx.doi .org/10.1037/a0013200

King, A. (1992). Comparison of self-questioning, summarizing, and notetaking-review as strategies for learning from lectures. American Educational Research Journal, 29, 303-323. http://dx.doi.org/ $10.3102 / 00028312029002303$

Komarraju, M., \& Nadler, D. (2013). Self-efficacy and academic achievement: Why do implicit beliefs, goals, and effort regulation matter? Learning and Individual Differences, 25, 67-72. http://dx .doi.org/10.1016/j.lindif.2013.01.005

Liem, A. D., Lau, S., \& Nie, Y. (2008). The role of self-efficacy, task value, and achievement goals in predicting learning strategies, task disengagement, peer relationship, and achievement outcome. Contemporary Educational Psychology, 33, 486-512. http://dx.doi.org/10.1016/j.cedpsych.2007.08.001

Linnenbrink-Garcia, L., Middleton, M. J., Ciani, K. D., Easter, M. A., O'Keefe, P. A., \& Zusho, A. (2012). The strength of the relation between performance-approach and performance-avoidance goal orientations: Theoretical, methodological, and instructional implications. Educational Psychologist, 47, 281-301. http://dx.doi.org/10.1080/ 00461520.2012 .722515

Linnenbrink-Garcia, L., Tyson, D. F., \& Patall, E. A. (2008). When are achievement goal orientations beneficial for academic achievement? A closer look at main effects and moderating factors. Revue Internationale de Psychologie Sociale, 1/2, 19-70.

Little, T. D., Cunningham, W. A., Shahar, G., \& Widaman, K. F. (2002). To parcel or not to parcel: Exploring the question, weighing the merits. Structural Equation Modeling, 9, 151-173. http://dx.doi .org/10.1207/S15328007SEM0902_1

Little, T. D., Rhemtulla, M., Gibson, K., \& Schoemann, A. M. (2013). Why the items versus parcels controversy needn't be one. Psychological Methods, 18, 285-300. http://dx.doi.org/10.1037/ a0033266

Macan, T. H., Shahani, C., Dipboye, R. L., \& Phillips, A. P. (1990). College students' time management: Correlations with academic performance and stress. Journal of Educational Psychology, 82, 760-768. http://dx.doi.org/10.1037/0022-0663.82 .4 .760

MacCann, C., Fogarty, G. J., \& Roberts, R. D. (2012). Strategies for success in education: Time management is more important for part-time than full-time community college students. Learning and Individual Differences, 22, 618-623. http://dx .doi.org/10.1016/j.lindif.2011.09.015

Meece, J. L., Wigfield, A., \& Eccles, J. S. (1990). Predictors of math anxiety and its influence on young adolescents' course enrollment intentions and performance in mathematics. Journal of Educational Psychology, 82, 60-70. http://dx.doi.org/ 10.1037/0022-0663.82.1.60

Midgley, C., Kaplan, A., \& Middleton, M. (2001). Performance-approach goals: Good for what, for whom, under what circumstances, and at what cost? Journal of Educational Psychology, 93, 7786. http://dx.doi.org/10.1037/0022-0663.93.1.77

Muis, K. R., \& Edwards, O. (2009). Examining the stability of achievement goal orientation. Contemporary Educational Psychology, 34, 265-277. http://dx.doi.org/10.1016/j.cedpsych.2009.06.003

Muis, K. R., \& Franco, G. M. (2009). Epistemic beliefs: Setting the standards for self-regulated learning. Contemporary Educational Psychology, 34, 306-318. http://dx.doi.org/10.1016/j.cedpsych .2009 .06 .005

Murayama, K., Elliot, A. J., \& Yamagata, S. (2011). Separation of performance-approach and performance-avoidance achievement goals: A broader analysis. Journal of Educational Psychology, 103, 238-256. http://dx.doi.org/10.1037/a0021948

Murayama, K., Pekrun, R., Lichtenfeld, S., \& Vom Hofe, R. (2013). Predicting long-term growth in students' mathematics achievement: The unique contributions of motivation and cognitive strategies. Child Development, 84, 1475-1490. http://dx .doi.org/10.1111/cdev.12036

Murphy, P. K., \& Mason, L. (2006). Changing knowledge and beliefs. In P. Alexander \& P Winne (Eds.), Handbook of educational psychology (2nd ed., pp. 305-324). Mahwah, NJ: Erlbaum.

Nett, U. E., Goetz, T., \& Daniels, L. M. (2010). What to do when feeling bored?: Students' strategies for coping with boredom. Learning and Individual Differences, 20, 626-638. http://dx.doi.org/ 10.1016/j.lindif.2010.09.004

Nett, U. E., Goetz, T., \& Hall, N. C. (2011). Coping with boredom in school: An experience sampling perspective. Contemporary Educational Psychology, 36, 49-59. http://dx.doi.org/10.1016/j .cedpsych.2010.10.003

Nett, U. E., Goetz, T., Hall, N. C., \& Frenzel, A. C. (2012). Metacognitive strategies and test performance: An experience sampling analysis of students' learning behavior. Education Research International, 2012, 1-16.

O'Brien, R. M. (2007). A caution regarding rules of thumb for variance inflation factors. Quality \& Quantity: International Journal of Methodology, 41, 673-690. http://dx.doi.org/10.1007/s11135006-9018-6

O'Keefe, P. A., Ben-Eliyahu, A., \& LinnenbrinkGarcia, L. (2013). Shaping achievement goal orientations in a mastery-structured environment and concomitant changes in related contingencies of 
self-worth. Motivation and Emotion, 37, 50-64. http://dx.doi.org/10.1007/s11031-012-9293-6

Pekrun, R. (1992). The expectancy-value theory of anxiety: Overview and implications. In D. G. Forgays, T. Sosnowski, \& K. Wrzesniewski (Eds.), Anxiety: Recent developments in self-appraisal, psychophysiological and health research (pp. 2341). Washington, DC: Hemisphere.

Pekrun, R. (2006). The control-value theory of achievement emotions: Assumptions, corollaries, and implications for educational research and practice. Educational Psychology Review, 18, 315341. http://dx.doi.org/10.1007/s10648-006-9029-9

Pekrun, R., Elliot, A. J., \& Maier, M. A. (2009). Achievement goals and achievement emotions: Testing a model of their joint relations with academic performance. Journal of Educational Psychology, 101, 115-135. http://dx.doi.org/10.1037/ a0013383

Pekrun, R., Goetz, T., Daniels, L. M., Stupnisky, R. H., \& Perry, R. P. (2010). Boredom in achievement settings: Exploring control-value antecedents and performance outcomes of a neglected emotion. Journal of Educational Psychology, 102, 531-549. http://dx.doi.org/10.1037/a0019243

Pekrun, R., Goetz, T., Frenzel, A. C., Barchfeld, P., \& Perry, R. P. (2011). Measuring emotions in students' learning and performance: The achievement emotions questionnaire (AEQ). Contemporary Educational Psychology, 36, 36-48. http://dx .doi.org/10.1016/j.cedpsych.2010.10.002

Pekrun, R., Goetz, T., Titz, W., \& Perry, R. P. (2002). Academic emotions in students' self-regulated learning and achievement: A program of qualitative and quantitative research. Educational Psychologist, 37, 91-105. http://dx.doi.org/10.1207/ S15326985EP3702_4

Pekrun, R., Hall, N. C., Goetz, T., \& Perry, R. P. (2014). Boredom and academic achievement: Testing a model of reciprocal causation. Journal of Educational Psychology, 106, 696-710. http://dx .doi.org/10.1037/a0036006

Pekrun, R., \& Linnenbrink-Garcia, L. (2012). Academic emotions and student engagement. In S. L. Christenson, A. L. Reschly, \& C. Wylie (Eds.), Handbook of research on student engagement (pp. 259-282). New York, NY: Springer. http://dx.doi .org/10.1007/978-1-4614-2018-7_12

Perry, R. P., Hladkyj, S., Pekrun, R., \& Pelletier, S. (2001). Academic control and action control in the achievement of college students: A longitudinal field study. Journal of Educational Psychology, 93, 776-789. http://dx.doi.org/10.1037/0022-0663 93.4 .776

Phan, H. P. (2008). Unifying different theories of learning: Theoretical framework and empirical evidence. Educational Psychology, 28, 325-340. http://dx.doi.org/10.1080/01443410701591392
Phan, H. P. (2009). Relations between goals, selfefficacy, critical thinking and deep processing strategies: A path analysis. Educational Psychology, 29, 777-799. http://dx.doi.org/10.1080/ 01443410903289423

Pintrich, P. R. (2004). A conceptual framework for assessing motivation and self-regulated learning in college students. Educational Psychology Review, 16, 385-407. http://dx.doi.org/10.1007/s10648004-0006-X

Pintrich, P. R., Smith, D., Garcia, T., \& McKeachie, W. (1991). A manual for the use of the motivated strategies for learning questionnaire (MSLQ). Ann Arbor, MI: University of Michigan.

Pintrich, P. R., Smith, D. A. F., Garcia, T., \& McKeachie, W. J. (1993). Reliability and predictive validity of the motivated strategies for learning questionnaire (MSLQ). Educational and Psychological Measurement, 53, 801-813. http://dx.doi .org/10.1177/0013164493053003024

Puente-Díaz, R. (2012). The effect of achievement goals on enjoyment, effort, satisfaction and performance. International Journal of Psychology, 47, 102-110. http://dx.doi.org/10.1080/00207594 .2011 .585159

Richardson, M., Abraham, C., \& Bond, R. (2012). Psychological correlates of university students' academic performance: A systematic review and meta-analysis. Psychological Bulletin, 138, 353387. http://dx.doi.org/10.1037/a0026838

Rosenberg, E. L. (1998). Levels of analysis and the organization of affect. Review of General Psychology, 2, 247-270. http://dx.doi.org/10.1037/10892680.2.3.247

Russell, J. A. (1980). A circumplex model of affect. Journal of Personality and Social Psychology, 39, 1161-1178. http://dx.doi.org/10.1037/h0077714

Ruthig, J. C., Perry, R. P., Hladkyj, S., Hall, N. C., Pekrun, R., \& Chipperfield, J. G. (2008). Perceived control and emotions: Interactive effects on performance in achievement settings. Social Psychology of Education, 11, 161-180. http://dx.doi.org/ 10.1007/s11218-007-9040-0

Sá, W. C., West, R. F., \& Stanovich, K. E. (1999). The domain specificity and generality of belief bias: Searching for a generalizable critical thinking skill. Journal of Educational Psychology, 91, 497510. http://dx.doi.org/10.1037/0022-0663.91.3 .497

Schukajlow, S., Leiss, D., Pekrun, R., Blum, W., Muller, M., \& Messner, R. (2012). Teaching methods for modeling problems and students' taskspecific enjoyment, value, interest and selfefficacy expectations. Educational Studies in Mathematics, 79, 215-237. http://dx.doi.org/ 10.1007/s10649-011-9341-2

Senko, C., Hama, H., \& Belmonte, K. (2013). Achievement goals, study strategies, and achieve- 
ment: A test of the "learning agenda" framework. Learning and Individual Differences, 24, 1-10. http://dx.doi.org/10.1016/j.lindif.2012.11.003

Senko, C., \& Miles, K. M. (2008). Pursuing their own learning agenda: How mastery-oriented students jeopardize their class performance. Contemporary Educational Psychology, 33, 561-583. http://dx .doi.org/10.1016/j.cedpsych.2007.12.001

Stupnisky, R. H., Renaud, R. D., Daniels, L. M. Haynes, T. L., \& Perry, R. P. (2008). The interrelation of first-year college students' critical thinking disposition, perceived academic control, and academic achievement. Research in Higher Education, 49, 513-530. http://dx.doi.org/10.1007/ s11162-008-9093-8

Swart, A. J., Lombard, K., \& de Jager, H. (2010). Exploring the relationship between time management skills and the academic achievement of African engineering students-A case study. European Journal of Engineering Education, 35, 7989. http://dx.doi.org/10.1080/03043790903480316

Toplak, M. E., \& Stanovich, K. E. (2002). The domain specificity and generality of disjunctive reasoning: Searching for a generalizable critical thinking skill. Journal of Educational Psychology, 94, 197-209.

Villavicencio, F. T. (2011). Critical thinking, negative academic emotions, and achievement: A meditational analysis. The Asia-Pacific Education Researcher, 20, 118-126.

Villavicencio, F. T., \& Bernardo, A. B. I. (2013) Positive academic emotions moderate the relationship between self-regulation and academic achievement. British Journal of Educational Psychology, 83, 329-340. http://dx.doi.org/10.1111/j .2044-8279.2012.02064.x

Vrugt, A., \& Oort, F. J. (2008). Metacognition, achievement goals, study strategies and academic achievement: Pathways to achievement. Metacog- nition and Learning, 3, 123-146. http://dx.doi.org/ 10.1007/s11409-008-9022-4

Watson, D., \& Tellegen, A. (1985). Toward a consensual structure of mood. Psychological Bulletin, 98, 219-235. http://dx.doi.org/10.1037/0033-2909 98.2.219

Winne, P. H., \& Hadwin, A. F. (1998). Studying as self-regulated learning. In D. J. Hacker, J. Dunlosky, \& A. Graesser (Eds.), Metacognition in educational theory and practice (pp. 277-304). Hillsdale, NJ: Erlbaum.

Wirthwein, L., Sparfeldt, J. R., Pinquart, M., Wegerer, J., \& Steinmayr, R. (2013). Achievement goals and academic achievement: A closer look at moderating factors. Educational Research Review, 10, 66-89. http://dx.doi.org/10.1016/j.edurev 2013.07.001

Yperen, N. W. V., Blaga, M., \& Postmes, T. (2014). A meta-analysis of self-reported achievement goals and nonself-report performance across three achievement domains (work, sports, and education). PLoS ONE, 9, 1-16.

Zeidner, M. (1998). Test anxiety: The state of the art. New York, NY: Plenum Press.

Zimmerman, B. J. (2000). Attainment of selfregulation: A social cognitive perspective. In $\mathrm{M}$. Boekaerts, P. Pintrich, \& M. Zeidner (Eds.), Selfregulation: Theory, research, and applications (pp. 13-39). Orlando, FL: Academic Press. http:// dx.doi.org/10.1016/B978-012109890-2/50031-7

Zimmerman, B. J., \& Campillo, M. (2003). Motivating self-regulatory problem solvers. In J. E. Davidson \& R. Sternberg (Eds.), The psychology of problem solving (pp. 233-262). New York, NY: Cambridge University Press. http://dx.doi.org/ 10.1017/CBO9780511615771.009 